\title{
Affective Aspects in Jurisprudence Based Online Learning Minister of Religion Decree 183 of 2019
}

\author{
Mohamad Erihadiana \\ Universitas Islam Negeri Sunan Gunung Djati Bandung \\ erihadiana@uinsgd.ac.id \\ Cecep Hilmi Nurdin \\ Universitas Islam Negeri Sunan Gunung Djati Bandung \\ hilwan17@gmail.com
}

\begin{abstract}
Online learning during a pandemic tends to overlook the affective aspects which are very important in the 2013 Curriculum. In line with the implementation of KMA 1832019 in the 2020/2021 school year, jurisprudence learning in madrasas must also adjust. This paper aims to suggest ways of applying the affective aspects even in online learning as it is today. Because online learning is very dependent on adequate technological literacy, while there are still many people who are not at that level. This research is a library research with a descriptive approach and the data collection technique uses library materials. The results of the study from various literature sources are concluded to be an explanation for solving the problem. From this research it was found that there are various ways that can be used to maintain the affective aspects of online learning, one of which is when in Basic Competence (KD) about spiritual aspects, namely: "Living and practicing everything that has been taught for good things is as a form of gratitude for the gift of Allah SWT", so to achieve this goal in online learning can be implemented using video media or film footage that explains and contains points to appreciate all the material tanght in figh learners as a gift from Allah SWT. The variety of ways of learning can be epective depending on the teacher's strategy and what media or learning services are used in the online learning being carried out.
\end{abstract}

Keywords: Affective Aspects, Online Learning, KMA 183 in 2019

Abstrak: Pembelajaran daring saat pandemi cenderung mengesampingkan aspek afektif yang sangatpenting dalam Kurikulum 2013. Sejalan dengan penerapan KMA 183 tahun 2019 di tahun ajaran 2020/2021, pembelajaran fikih di madrasah pun harus menyesuaikan. Tulisan ini bertujuan untuk mengemukakan cara-cara penerapan aspek afektif walaupun dalam pembelajaran daring seperti saat ini. Sebab pembelajaran daring sangat bergantung pada kemelekan teknologi yang memadai, sementara masih banyak masyarakat belum berada pada level tersebut. Penelitian ini berjenis penelitian pustaka dengan pendekatan deskriptif dan teknik pengumpulan data menggunakan bahan pustaka. Hasil kajian dari berbagai sumber literatur disimpulkan menjadi suatu penjelasan untuk memecahkan masalah. Dari penelitian ini ditemukan bahwa ada berbagai cara yang dapat digunakan untuk mempertahankan aspek afektif dalam pembelajaran daring,salah satunya ialah ketika dalam Kompetensi Dasar (KD) tentang aspek spiritual yaitu: "Menghayati dan mengamalkan semua yang telah diajarkan untuk hal-hal yang baik adalah sebagai wujud syukur atas anugerah Allah swt", maka untuk mencapai tujuan tersebut dalam pembelajaran daring dapat diimplementasikan menggunakan media video atau cuplikan film yang menerangkan dan mengandung poin menghayati semua materi yang diajarkan dalam pembelajar fikih sebagai anugerah dari Allah swt. Kebervariasian cara dalam pembelajaran dapat efektif bergantung pada strategi guru dan media atau layanan belajar apa yang digunakan dalam pembelajaran daring yang dilaksanakan.

Kata Kunci: Aspek afektif, Pembelajaran daring, KMA 183 tahun 2019 


\section{PENDAHULUAN}

Kemunculan virus Covid-19 di tanah air mengakibatkan dampak yang begitu besar di segala kehidupan masyarakat Indonesia. Bisa dibilang virus ini cukup banyak mengganggu tatanan kehidupan masyarakat Indonesia dan bahkan dunia. Pandemi global ini mengharuskan sebagian besar masyarakat menetap dan menjalankan aktifitasnya di rumah. Dan jika harus pergi keluar, itu pun apabila terdapat keperluan yang sangat penting atau tuntutan pekerjaan yang tidak dapat dikerjakan dari rumah. Di tempat-tempat umum, protokol kesehatan sangat ditekankan.

Covid-19 sebagai pandemi global ini tidak dapat dipungkiri sangat berdampak pada pendidikan di Indonesia. Sejak pertengahan maret 2020 lalu, lembaga-lembaga pendidikan di seluruh Indonesia mulai memindahkan kegiatan belajar mengajarnya ke rumah peserta didik masing-masing sejalan edaran dari Kementerian Pendidikan dan Kebudayaan tak terkecuali madrasah-madrasah yang bernaung di bawah Kementerian Agama. Sekolah-sekolah di seantero negeri mau tidak mau harus memahami keadaan yang sedang terjadi. Bagaimana pun caranya kegiatan belajar mengajar harus tetap berjalan walaupun tanpa tatap muka langsung. Pembelajaran secara daring atau online adalah solusinya.

Pembelajaran daring adalah sebuah sistem pembelajaran yang menggunakan dan memanfaatkan layanan jaringan internet dalam prosesnya. ${ }^{1}$ Pembelajaran daring sebagai alternatif bagi dunia pendidikan di tengah pandemi ini dilakukan dalam berbagai macam bentuk. Segala sesuatu akan disesuaikan dengan sumber daya dan kemampuan yang ada, baik dari segi peserta didik maupun guru.

Kebijakan belajar dari rumah telah merubah pola belajar para siswa. Hal ini tentu tidak akan langsung bisa berjalan dengan baik, karena selama ini telah terbiasa belajar secara tatap muka. Menurut Husamah dalam I Ketut Sudarsana dkk secara umum, pembelajaran tatap muka memiliki berbagai kelebihan rerbadap pengajar maupun peserta didik, antara lain: 1)Disiplin formal yang diterapkan pada pembelajaran tatap muka dapat membentuk disiplin mental; 2)Memudahkan pemberian penguatan (reinforcement) dengan segera: 3)Memudahkan proses penilaian oleh pendidik; 4)Menjadi wahana belajar berinteraksi terhadap peserta didik. Kelebihan lainnya yaitu kemampuan sosialisasi antara pendidik dengan peserta didik, maupun antar sesama peserta Dasar."

${ }^{1}$ Dewi, "Dampak COVID-19 Terhadap Implementasi Pembelajaran Daring Di Sekolah 
didik. Tidak hanya itu saja, pendidik dapat mengamati secara langsung sikap dan tingkah laku peserta didik dalam menerima materi. ${ }^{2}$

Dalam pelaksanaan Pendidikan Jarak Jauh, seringkali ditemukan kendala ataupun ketidaksesuaian dengan pembelajaran yang seharusnya, banyak yang mengira tanggung jawab pengajar dalam melaksanakan daring jauh lebih ringan ketimbang dengan Pembelajaran tradisional. ${ }^{3}$ Saat ini system pendidikan mendapat banyak masalah, dalam masa pandemi Covid-19 pembelajaran di Indonesia dialihkan menjadi Pendidikan jarak jauh, namun kurangnya peralatan, personel, sumber daya, dan keterbatasan teknologi pendidikan, serta keterampilan dan kualitas yang dimiliki pengajar belum mencukupi. Penggunaan media belajar online atau e-learning memiliki kendala yang cukup besar, koneksi jaringan dan kesalahan teknis seperti server down and error dapat menghambat keberhasilan pembelajaran. ${ }^{4}$ Masih banyak kendala yang dapat terjadi dalam pembelajaran daring, seperti kurang pahamnya peserta didik dalam penggunaan aplikasi belajar online, tidak memiliki kuota data internet, tidak memiliki HP Android dan lain-lain. Meskipun begitu, selain sarana atau media yang mendukung proses pembelajaran, keberhasil belajar daring juga dipengaruhi oleh karakteristik peserta didik, seperti yang diungkapkan Wahyu Aji Fatma Dewi bahwa keberhasilan dari suatu model ataupun media pembelajaran tergantung dari karakteristik peserta didiknya. ${ }^{5}$

Pembelajaran secara daring ini tentunya tidak akan sama dengan pembelajaran dalam bentuk tatap muka langsung di kelas. Terlepas dari segala kelebihannya, ada satu hal yang menurut penulis masih abu-abu dalam pembelajaran daring yaitu penerapan aspek afektif dalam pelaksanaannya. Pada aspek kognitif dinilai tidak begitu jauh dengan pembelajaran tatap muka walaupun memang tidak akan pernah sama dengan pembelajaran luring seperti biasa. Sementara aspek afektif yaitu sikap spiritual ataupun sikap sosial sebagaimana tersyaratkan dalam kompetensi inti (KI) dan kompetensi dasar (KD) agaknya cukup terkendala dimana jika dibandingkan dengan pembelajaran di kelas, hal itu relatif mudah dilaksanakan karena para peserta didik terkumpul

${ }^{2}$ I Ketut Sudarsana et al., Covid-19: Perspektif Pendidikan, ed. Kadek Aria Prima Dewi PF and Janner Simarmata, Cetakan 1 (Medan: Yayasan Kita Menulis, 2020).

${ }^{3}$ Ilona Semradova and Sarka Hubackova, "Teacher Responsibility in Distance Education," Procedia - Social and Behavioral Sciences 217 (2016): 544-50, https://doi.org/10.1016/j.sbspro.2016.02.042.

${ }^{4}$ Widya Sari, Andi Muhammad Rifki, and Mila Karmila, "Pembelajaran Jarak Jauh Pada Masa Darurat Covid 19," Jurnal MAPPESONA, no. 1 (2020): 12, https://jurnal.iainbone.ac.id/index.php/mappesona/article/view/830.

${ }^{5}$ Wahyu Aji Fatma Dewi, "Dampak COVID-19 Terhadap Implementasi Pembelajaran Daring Di Sekolah Dasar," Edukatif: Jurnal Ilmu Pendidikan 2, no. 1 (2020): 55-61, https://doi.org/10.31004/edukatif.v2i1.89. 
dan saling berinteraksi serta bertatap muka langsung dengan guru yang bersangkutan. Ditambah lagi penilaian terhadap kompetensi ini juga lebih sulit dilakukan oleh para guru sebab guru tidak memperhatikan perilaku peserta didik secara langsung.

Adanya keputusan meteri agama (KMA) terbaru tentang kurikulum PAI dan Bahasa Arab baru-baru ini juga turut menjadi tantangan tersendiri bagi para guru. Belum beradaptasi dengan pandemi, para guru di tanah air sudah dihadapkan lagi dengan tantangan baru yakni penerapan KMA 183 dan KMA 184 yang dimulai pada tahun ajaran 2020/2021. ${ }^{6}$ KMA 183 tahun 2019 yang berisi tentang Kurikulum Baru PAI dan Bahasa Arab ini memiliki perbedaanperbedaan dengan KMA sebelumnya, KMA 165 tahun 2014. Perbedaan yang paling mudah diidentifikasi yakni pada segi Kompetensi Inti (KI) dan Kompetensi Dasar (KD) serta topik pembahasan materinya. Tentu para guru harus memodifikasi kembali perangkat pembelajarannya menyesuaikan dengan tuntutan kurikulum yang baru diberlakukan ini.

Maka berdasarkan latar belakang yang telah diuraikan di atas, tulisan ini hendak membahas tentang aspek afektif dalam pembelajaran daring Fikih berdasarkan KMA 183 tahun 2019.

\section{HASIL dan PEMBAHASAN}

\section{Hakikat Afektif dalam Pembelajaran}

Menurut Cronbach belajar adalah proses terjadinya perubahan kelakukan yang dihasilkan oleh pengalaman. ${ }^{7}$ Sementara menurut Kingsley menyebutkan bahwa belajar merupakan sebuah proses yang dimana prilakudirubah dan dibentuk melalui praktik dan latihan. ${ }^{8}$ Berdasarkan dua definisi ahli tersebut bisa diketahui bahwa belajar hakikatnya merupakan sebuah proses pembentukan dan perubahan prilaku yang dicapai melalui berbagai kegiatan praktik dan latihan. Praktik dan latihan ini lah yang diterapkan padaaktivitas belajar di kelas.

Dalam proses belajar dan mengajar, tidak semata-mata mengkaji aspek pengetahuan saja. Menurut Bloom dan Wohl, terdapat tiga ranah dalam pembelajaran yaitu kognitif, afektif, dan psikomotorik. ${ }^{9}$ Kognitif lebih dikenal dengan aspek pengetahuan, afektif sebagai aspek sikap, dan psikomotorik sebagai aspek keterampilan.

\footnotetext{
"Madrasah, "KMA 183 Tahun 2019 Tentang Kurikulum PAI Dan Bahasa Arab."

${ }^{7}$ Cronbach, Educational Psychology. Hlm.47

${ }^{8}$ Garry, L., and Kingsley, The Nature and Conditions of Learning.

${ }^{9}$ Hamzah, “Aspek Pengembangan Peserta Didik: Kognitif, Afektif, Psikomotorik."
} 
Kata afektif berasal dari bahasa Inggris yaitu affective yang artinya unsur yang berhubungan dengan nilai dan sikap. Menurut Popham, ranah afektif merupakan sesuatu yang berkaitan dengan emosi, perasaan, sikap hati, dan sistem nilai yang memperlihatkan penerimaan atau penolakan terhadap sesuatu, serta apresiasi dan penyesuaian perasaan. ${ }^{10}$ Jadi, ranah afektif dalam pembelajaran berbicara tentang sikap, emosi, perasaan dan apresiasi seorang peserta didik terhadap segala sesuatu yang ada dalam pembelajaran itu sendiri baik itu terhadap sesama elemen pembelajaran maupun materi dan bahan ajar. Sejalan dengan Popham, Suliswiyadi mengemukakan bahwa wilayah afektif meliputi minat, kehendak, ketertarikan, perasaan, nilai, sikap dan emosi peserta didik terhadap pembelajaran. Menurutnya capaian afektif peserta didik ditunjukkan oleh perilakunya terhadap pembelajaran itu sendiri. ${ }^{11}$

Dalam Soetam Rizky Wicaksono mengungkapkan bahwa domain afektif menurut David Krathwoll, taksonomi Bloom memiliki beberapa tingkatan, yaitu: receiving (attending), responding, valuing, organizing, dan characterization by avalue atau value complex. ${ }^{12}$ Secara rinci domain afektifmemiliki tingkatan-tingkatan sebagai berikut:

Tabel 1.1

Tingkatan-tingkatan Domain Afektif menurut Taksonomi Bloom

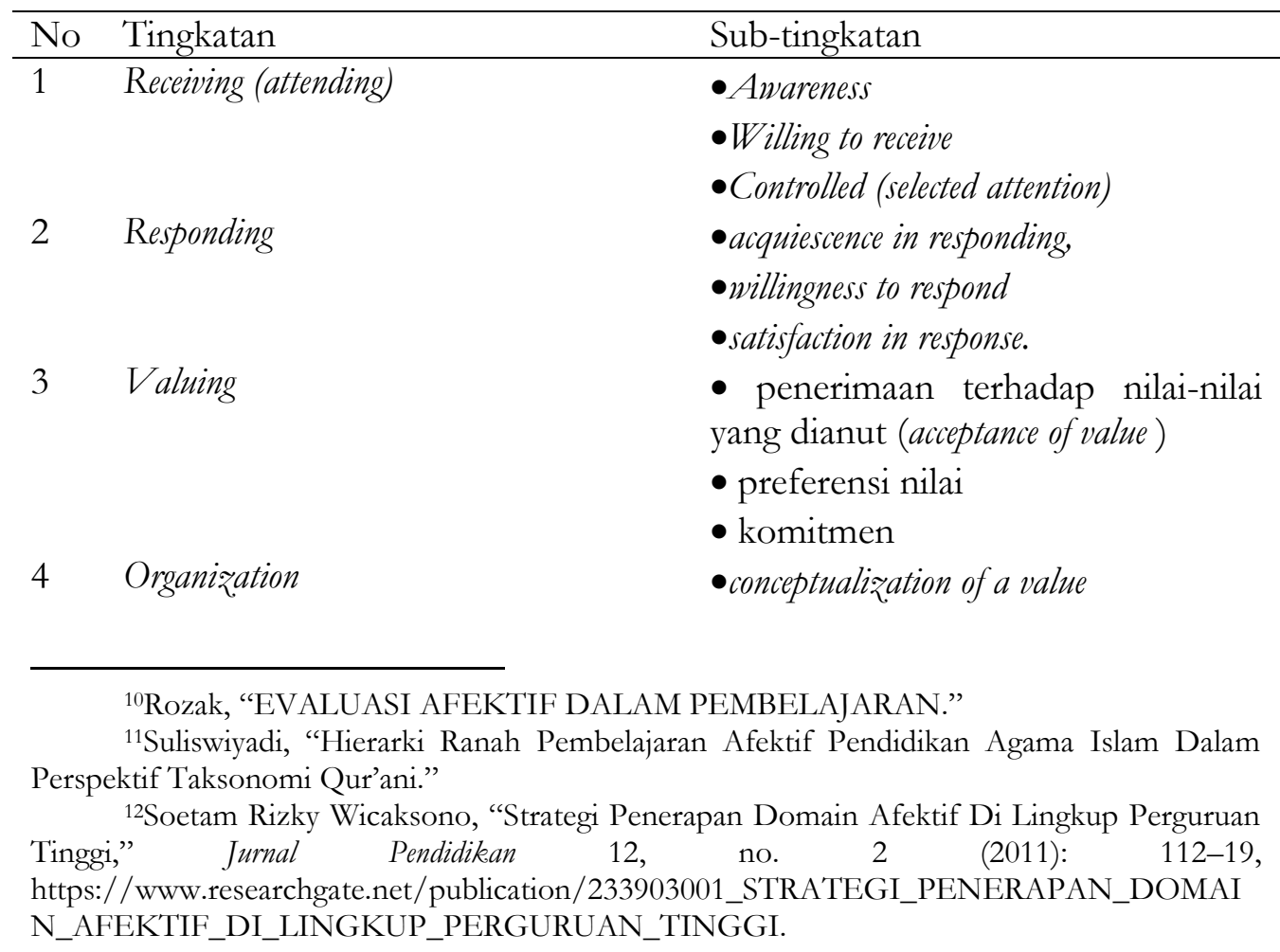




\section{$5 \quad$ Characterization by value (value Complex)}

- organization of a value system.

- generalized set

- characterization

Pada tingkatan receiving (attending), fokus pembelajaran adalah pada asumsi, artinya pada saat pembelajar diberi penjelasan tentang sebuah fenomena atau diberi stimulus, maka pembelajar akan mau menerima keberadaan fenomena atau stimulus tersebut. Terdapat 3 (tiga) sub tingkatan,yaitu kesadaran (awareness), kemauan untuk menerima (willingness to receive), dan perhatian tertentu (selected attention). Kesadaran agak berbeda dengan perilaku kognitif, terutama pada saat merespon sebuah stimulus. Didalam perilaku kognitif, pembelajar dapat mengungkapkan respon atas sebuah stimulus,sedangkan di sub level ini pembelajar hanya menerima stimulus tersebut tanpa ada kewajiban untuk menyatakan sebuah respon. Sebagai contoh, pembelajar hanya memperhatikan lingkungan sekitar yang dianggap menarik seperti perabot kelas, bangunan sekolah tanpa memberikan komentar.

Pada sub level kemauan untuk menerima, pembelajar hanya memiliki kemauan untuk menerima stimulus yang diberikan oleh pengajar, sehingga pembelajar hanya berada dalam keadaan pasif menerima dengan cara memperhatikan apa yang diberikan kepadanya. Contoh di sub level ini adalah pada saat pembelajar telah bersedia untuk memperhatikan apa yang diucapkan oleh sang pengajar, meski tidak harus mampu memahami apa yang sedang diucapkan, tetapi sudah terdapat kemauan untuk berusaha fokus kepada apa yang sedang dikatakan atau sedang diterangkan pada saat itu.

Pada sub level yang ke-3 yaitu perhatian tertentu (selected attention), pembelajar telah mampu menerima stimulus secara sadar sehingga mampu memilah dengan baik stimulus yang diberikan oleh pengajar di luar stimulus yang ada pada saat itu. Sebagai contoh, si pembelajar telah mampu memilah antara satu rumus dengan rumus yang lain dalam sebuah pelajaran di bidang sains.

Pada tingkatan menanggapi (responding), fokus pembelajaran adalah pada respon individu terhadap suatu fenomena, jadi lebih dari hanya sekadar memperhatikan. Pada tingkatan ini seorangpengajar dapat melihat secara langsung ketertarikan si pembelajar pada materi yang sedang diajarkan pada saat itu. Pada tingkatan ini, terdapat 3 (tiga) sub tingkatan, yaitu: acquiescencein responding, willingness to respond, dan satisfactionin response. Pada sub tingkatan persetujuan dalam merespon (acquiescence in responding), pembelajar mulai menunjukkan kepatuhan terhadap peraturan yang diterapkan atau menunjukkan reaksi terhadap kewajiban yang disampaikan oleh pengajar. Demikian pula, pada willingness to respond si pembelajar telah menunjukkan sikap sukarela dalam 
melaksanakan tugas yang diberikan oleh pengajar. Sedangkan pada sub-tingkatan satisfaction in response, pengajar dapat melihat secara jelas kepuasan dan rasa senang yang ditunjukkan oleh para pembelajar secara eksplisit.

Pada tingkatan valuing, pembelajar akan menunjukkan komitmennya berdasarkan nilai yang dianutnya yang selanjutnya akan menuntun perilaku pembelajar. Kondisi ini sangat berbeda dengan konsep motivasi eksternal yang hanya mengarah kepada kepatuhan. Terdapat 3 (tiga) sub tingkatan valueing, yaitu penerimaan terhadap nilai-nilai yang dianut (acceptance of value), preferensi nilai, dan komitmen. Pada sub-tingkatan acceptance of value, pembelajar telah memiliki keyakinan bahwa dirinya telah memiliki nilai-nilai tertentu dalam dirinya dan memiliki kemauan untuk dapat diidentifikasi oleh orang lain berdasarkan keyakinan tersebut. Misalnya, seorang siswa memiliki keyakinan bahwa dirinya dapat bertoleransi dengan banyak orang yang berasal dari berbagai daerah asal. Pada subtingkatan preference of value, pembelajar tidak hanya yakin pada nilai yang telah dia miliki, namun juga berusaha untuk mempertahankan nilai-nilai tersebut. Sedangkan pada sub-tingkatan commitment, seseorang tidak hanya percaya terhadap suatu nilai tetapi juga berusaha berkomitmen kepada nilai tersebut sehingga pada akhirnya akan menjadi sebuah motivasi dalam melakukan suatu tindakan.

Pada tingkatan organisasi (organization), pembelajar sudah sampai pada tahapan mempercayai nilai-nilai tertentu, selanjutnya ia akan dihadapkan pada lebih dari satu nilai atau beberapa nilai yang harus dipercayainya. Pada tingkatan ini, pembelajar mulai mengorganisasi nilainilai tersebut dan mencari hubungan antara satu nilai dengan nilai yang lain, dan selanjutnya berusaha menemukan nilai yang menurutnya paling dominan. Organization memiliki 2 (dua) sub tingkatan, yaitu: conceptualization of a value dan organization of a value system. Sebagai lanjutan dari level sebelumnya, maka pada conceptualization of a value, seorang pembelajar mulai merelasikan nilai-nilai yang dia miliki dan berusaha mencari nilai mana yang seharusnya dia pegang teguh. Selanjutnya, setelah melakukan abstraksi dari nilai yang dia miliki pada sub-tingkatan organization of a value system, pembelajar akan berusaha mengorganisasi seluruh nilai yang ia temukan.

Pada tingkatan yang terakhir yaitu characterization by value set atau value complex, pembelajar dianggap telah memiliki nilai yang kuat di dalam dirinya, maka ia akan berusaha melakukan generalisasi terhadap perilakunya dan mengintegrasikan keyakinan, ide dan tingkah laku menjadi sebuah filosofi hidup. Terdapat dua sub level yaitu: generalized set dan characterization. Pada sub-tingkatan generalized set, seorang pembelajar telah mampu bersikap konsisten dari dalam diri sendiri atau internal berdasarkan nilai-nilai yang telah ia miliki. Sedangkan subtingkatan characterization merupakan puncak dari proses internalisasi. Karenanya, 
pada sub level ini pembelajar telah mampu memiliki filosofi pribadi yang kuat dan konsisten.

Ranah afektif dalam pembelajaran dengan Kurikulum 2013 jauh lebih ditekan. Hal ini berbeda dengan kurikulum yang sebelumnya yang hanya menitik beratkan keberhasilan pembelajaran pada aspek kognitif. Sebelumnya penilaian hanya pada aspek kognitif peserta didik. Akan tetapi dengan melihat keadaan yang ada, perlu adanya penguatan karakter peserta didik yang diwujudkan dalam bentuk Kurikulum 2013. Dengan penerapan Kurikulum 2013 penilaian juga berpatokan pada aspek afektifnya dalam pelaksanaannya di lembaga-lembaga pendidikan tak tercuali madrasah. Ditambah lagi dengan ditetapkannya KMA 183 dan 184 tahun 2019 yang mewajibkan menanamkan nilai kesederhanaan agama dan memperkuat pendidikan karakter dan pendidikan anti korupsi bagi siswa pada setiap pelajaran agama Islam dan bahasa Arab.

Transformasi kurikulum ini berhubungan erat dengan isu-isu yang mulai dan tengah terjadi sekarang yaitu degradasi moral pada generasi muda. Menurut Zubaedi dikutip oleh Pulungan, masalah tersebut bersumber dari ketidaksusesan sistem pendidikan nasional dalam mengoptimalkan pembentukan karakter pada diri peserta didik. Lembagai pendidikan dinilai mengesampingkan aspek afektif dalam proses evaluasinya. ${ }^{13}$ Padahal di negara-negara maju di luar sana, justru jauh lebih menekankan dan mendahulukan aspek sikap sebelum beranjak ke kognitif atau pengetahuan peserta didik. Terlebih lagi pada mata pelajaran yang seharusnya mengedepankan pembiasaan karakter baik, malah condong memperhatikan kognitif dalam penilaiannya. Dimana seharusnya dapat menjadi sarana pembentukan karakter peserta didik.

Ranah afektif dalam Kurikulum 2013 terbagi ke dalam dua bagian, sikap spiritual dan sikap sosial. ${ }^{14}$ Sikap spiritual adalah ranah afektif siswa yang terwujud melalui hubungannya dengan Tuhan YME. Sementara sikap sosial diwujudkan dalam bentuk interaksi peserta didik dengan lingkungan sosial sekitar.

Dengan diterapkannya kurikulum 2013 maka kemampuan guru dalam pengimplementasian elemen-elemen di dalamnya mutlak dibutuhkan. Terlebih lagi kurikulum ini juga lebih menekankan pada aspek sikap atau afektif peserta didik. Bahkan penilaiannya pun sangat berbeda dengan apa yang ada pada kurikulum sebelumnya. Sehingga tidak heran banyak dari guru sedikit kebingungan dengan sistem tersebut.

\footnotetext{
13Pulungan, "Pembelajaran Ranah Afektif Antara Harapan Dan Kenyataan."

${ }^{14}$ Pranjia, Ulpa, and Manthika, "IMPLEMENTASI SIKAP SPIRITUAL DAN SIKAP SOSIAL DALAM SISTEM FULL DAY SCHOOL."
} 
Tidak ada materi dasar untuk kemampuan mental dan sikap sosial, sehingga kemampuan dasar tidak boleh diajarkan dan dihafal sebagaimana kompetensi kognitif dan psikomotirk. Akan tetapi hal ini menjadi bimbingan bagi guru dalam menyampaikan informasi spiritual dan sosial saat mengajarkan mata pelajaran ini,serta harus disampaikan dan dibiasakan kepada peserta didik. ${ }^{15}$ Tentunya pelaksanaan hal ini tidak terlepas dari kompetensi dasar yang telah tercantum dalam silabus.

Aspek ini diterapkan tidak lain adalah sebagai cara kognitif untuk meningkatkan minat dan motivasi siswa. ${ }^{16}$ Sulit bagi siswa yang tidak tertarik pada mata pelajaran tertentu untuk mencapai keberhasilan belajar yang maksimal. ${ }^{17} \mathrm{Hal}$ ini pula yang menjadi tugas tersendiri bagi para guru. Bagaimana memberikan pengajaran yang sebaik mungkin sehingga minat dan motivasi belajar peserta didik dapat dicapai dan dipertahankan sekaligus ditingkatkan.

Secara tidak langsung aspek sikap spiritual dan sikap sosial ini diterapkan sekaligus dinilai. Melihat hal ini maka guru disyaratkan untuk memiliki kemampuan mentransfer nilai-nilai sikap spiritual dan sosial ini kepada peserta didik. Dalam upaya mencapai ketersampaian ini, guru harus didukung oleh RPP yang baik dengan indikator-indikator yang dapat dengan mudah diaplikasikan sekaligus diidentifikasi ketercapaiannya. ${ }^{18}$ Penggunaan variasi metode dan media dalam pembelajaran jugamutlak dibutuhkan dan harus diterapkan oleh guru. Sekalipun begitu, tetap harus dipahami pula bahwa setiap guru memiliki kemampuan dan karakteristik yang berbeda-beda. Akibatnya tidak semua guru dapat mengajarkan pelajarannya sesuai dengan kemauan setiap peserta didik.

\section{KMA 183 tahun 2019 vs KMA 165 tahun 2014 Pada Segi Muatan KD}

Pada pembahasan sebelumnya telah disinggung terkait perubahanperubahan yang terjadi mengingat diterapkannya KMA 183 pada tahun ajaran 2020/2021 ini. Ada hal-hal baru yang tercantum di KMA tersebut yang menarik untuk dibahas dan tentunya perlu mengingat guru-guru yang sebelumnya berpedoman pada KMA 165 kini harus menyesuaikan kembali dengan KMA yang terbaru.

Salah satu hal yang cukup mencolok perbedaannya dari KMA sebelumnyaadalah muatan kompetensi dasar. Berikut dijabarkan contoh

\footnotetext{
${ }^{15}$ Oviana, "Kemampuan Mahasiswa Mengintegrasikan Sikap Spiritual Dan Sosial Dalam Pembelajaran Berbasis Kurikulum 2013 (Kajian Teoritis)."

${ }^{16}$ Qadar, "Mengakses Aspek Afektif Dan Kognitif Pada Pembelajaran Optika Dengan Pendekatan Demonstrasi Interaktif."

17Pulungan, "Pembelajaran Ranah Afektif Antara Harapan Dan Kenyataan."

${ }^{18}$ Oviana, "Kemampuan Mahasiswa Mengintegrasikan Sikap Spiritual Dan Sosial Dalam Pembelajaran Berbasis Kurikulum 2013 (Kajian Teoritis)."
} 
perbandingan muatan kompetensi dasar FikihMadrasah Aliyah di KMA 165 dan KMA 183, mengambil contoh pada kelas X MA Peminatan IPA, IPS, Bahasa dan MA Kejuruan.

\section{Tabel 2.1}

Perbandingan KD Fikih Kelas X MAPeminatan IPA, IPS, Bahasa dan MA Kejuruan Semester Ganjil KMA 165 dengan KMA 183

\begin{tabular}{|c|c|c|c|}
\hline $\mathrm{No}$ & KD di KMA 165 & $\mathrm{No}$ & KD di KMA 183 \\
\hline 1.1 & $\begin{array}{l}\text { Meyakini kesempurnaan ajaran } \\
\text { agama Islam melalui } \\
\text { komlpleksitas aturan fikih }\end{array}$ & 1.1 & $\begin{array}{l}\text { Menghayati kesempurnaan } \\
\text { ajaran Islam melalui aturan fikih } \\
\text { yang komprehensif }\end{array}$ \\
\hline 1.2 & $\begin{array}{l}\text { Meyakini syariat Islam tentang } \\
\text { kewajiban penyelenggaraan } \\
\text { jenazah }\end{array}$ & 1.2 & $\begin{array}{l}\text { Menghayati pentingnya syariat } \\
\text { Islam tentang kewajiban } \\
\text { pemulasaraan jenazah }\end{array}$ \\
\hline 1.3 & $\begin{array}{l}\text { Meyakini kebenaran konsep } \\
\text { zakat dalam mengurangi } \\
\text { kesenjangan antara yang kaya } \\
\text { dan yang Miskin }\end{array}$ & 1.3 & $\begin{array}{l}\text { Menghayati ketentuan zakat } \\
\text { dalam mengurangi kesenjangan } \\
\text { antara yang kaya dan yang } \\
\text { miskin }\end{array}$ \\
\hline 1.4 & $\begin{array}{l}\text { Menghayati hikmah pelaksanaan } \\
\text { ibadah haji dan umrah }\end{array}$ & 1.4 & $\begin{array}{l}\text { Menghayati nilai-nilaipositif dari } \\
\text { pelaksanaanibadah haji dan } \\
\text { umrah }\end{array}$ \\
\hline 1.5 & $\begin{array}{l}\text { Menghayati nilai-nilai mulia dari } \\
\text { syraiat kurban dan akikah }\end{array}$ & 1.5 & $\begin{array}{l}\text { Menghayati nilai-nilai mulia dari } \\
\text { pelaksanaan syariat qurban dan } \\
\text { aqiqah }\end{array}$ \\
\hline 2.1 & $\begin{array}{l}\text { Menunjukkan perilaku taat } \\
\text { terhadap ketentuan hukum fikih } \\
\text { dalam kehidupan sehari-hari }\end{array}$ & 2.1 & $\begin{array}{l}\text { Mengamalkan sikap patuh dan } \\
\text { tanggung jawab dalam } \\
\text { kehidupan sehari-hari }\end{array}$ \\
\hline 2.2 & $\begin{array}{l}\text { Memiliki rasa tanggung jawab } \\
\text { tentang kewajiban } \\
\text { penyelenggaraan jenazah }\end{array}$ & 2.2 & $\begin{array}{l}\text { Mengamalkan sikap tanggung } \\
\text { jawab, peduli dan gotong royong } \\
\text { dalam kehidupan sehari-hari }\end{array}$ \\
\hline 2.3 & $\begin{array}{l}\text { Memiliki kepekaan sosial sebagai } \\
\text { implementasi dari nilai-nilai yang } \\
\text { terdapat pada zakat }\end{array}$ & 2.3 & $\begin{array}{l}\text { Mengamalkan sikap peduli sosial } \\
\text { dan responsif dalam kehidupan } \\
\text { sehari-hari }\end{array}$ \\
\hline 2.4 & $\begin{array}{l}\text { Membiasakan sikap kerja sama, } \\
\text { dantolong-menolong sebagai } \\
\text { implementasihikmah dari ibadah }\end{array}$ & 2.4 & $\begin{array}{l}\text { Mengamalkan sikapdisiplin, } \\
\text { tanggungjawab dan gotong } \\
\text { royong dalam kehidupan sehari- }\end{array}$ \\
\hline
\end{tabular}




\begin{tabular}{|c|c|c|c|}
\hline & haji dan umrah & & hari \\
\hline 2.5 & $\begin{array}{l}\text { Membiasakan sikap peduli } \\
\text { kepada orang lain sebagai } \\
\text { impelementasi dari nilai-nilai } \\
\text { yang terdapat pada ibadah } \\
\text { kurban dan akikah }\end{array}$ & 2.5 & $\begin{array}{l}\text { Mengamalkan sikap peduli, } \\
\text { tanggungjawab dan rela } \\
\text { berkorban sebagai implementasi } \\
\text { dari mempelajari qurban dan } \\
\text { aqikah }\end{array}$ \\
\hline
\end{tabular}

\section{Penerapan Afektif dalam Pembelajaran Daring Fikih}

Pembahasan poin ini difokuskan kepada pembelajaran fikih di kelas X MA sebagai contoh. Di dalam mata pelajaran fikih untuk madrasah aliyah sendiri kompetensi inti dirumuskan berdasarkan standar kompetensi lulusan (SKL). Adapun kompetensi inti ranah afektif pada mata pelajaran fikih kelas X sesuai dengan KMA 183 tahun 2019 adalah sebagai berikut:

Tabel 2.2

Kompetensi Inti Fikih kelas X

\begin{tabular}{|c|c|}
\hline Domain & Kompetensi Inti \\
\hline Sikap Spiritual & Menghayati dan mengamalkan ajaran agama yang dianutnya \\
\hline Sikap Sosial & $\begin{array}{l}\text { Menunjukkan perilaku jujur, disiplin, bertanggungjawab, } \\
\text { peduli (gotong royong, kerjasama, toleran,damai), santun, } \\
\text { responsif, dan proaktif sebagai bagian dari solusi atas berbagai } \\
\text { permasalahan dalam berinteraksi secara efektif dengan } \\
\text { lingkungan sosial dan alam serta menempatkan diri sebagai } \\
\text { cerminan bangsa dalam pergaulan dunia }\end{array}$ \\
\hline
\end{tabular}

Berdasarkan kompetensi inti tersebut, dapat dilihat bahwa butir-butir nilai yang harus diterapkan guru adalah kejujuran, kedisiplinan, tanggung jawab, kepedulian, sopan santun responsif dan proaktif. Nilai-nilai tersebut diharapkan dapat diterapkan oleh para peserta didik dalam kehidupan keseharian mereka. Tetapi dalam keadaan belajar di rumah selama pandemi ini, tentunya perlu adanya penyesuaian terhadapnya. Kompetensi inti tersebut diuraikan menjadi kompetentis-kompetensi dasar yang telah diuraikan pada pembahasan sebelumnya.

Sebelum membahas penerapan afektif dalam pembelajaran daring. Baik untuk memahami lima tingkatan afektif. Menurut Krathwol dkk dikutip oleh 
Pohan mengemukakan bahwa terdapat lima tingkatan dalam kemampuan aspek afektif. $^{19}$

\section{Tabel 2.3.}

Tabel Tingkatan Kemampuan dalam Ranah Afektif

\begin{tabular}{|c|c|}
\hline & Kemampuan dalam ranah \\
\hline Menerima & $\begin{array}{l}\text { Kemampuan untuk fokus pada suatu kegiatan atau kejadian } \\
\text { yang akan datang. }\end{array}$ \\
\hline Merespon & $\begin{array}{l}\text { Kemampuan menanggapi kegiatan melalui partisipasi atau } \\
\text { melibatkan diri pada kegiatan tersebut. }\end{array}$ \\
\hline Mem & $\begin{array}{l}\text { Kemampuan menerima atau menolak nilai atau norma yang } \\
\text { diekspresikan dalam sikap positif atau negatif. }\end{array}$ \\
\hline Mengorganisasi & $\begin{array}{l}\text { Mampu mengidentifikasi, memilih dan menentukan nilai } \\
\text { atau spesifikasi yang akan diterapkan. }\end{array}$ \\
\hline Memberikarakter & $\begin{array}{l}\text { Mempercayai, mengaplikasikan, dan membuktikan perilaku } \\
\text { yang konsisten dengan nilai dan norma yang dipelajari. }\end{array}$ \\
\hline \multicolumn{2}{|c|}{$\begin{array}{l}\text { Perlu dipahami aspek afektif diterapkan dengan strategi yang tidak } \\
\text { samapadaproses pembelajaran yang bersifat kognitif dan psikomorik. } \\
\text { Sedangkan, Afektif sendiri melibatkan nilai yang pada umumnya sulit diukur dan } \\
\text { dinilai. }{ }^{20} \text { Namun, aspek ini tetap dapat dinilai melalui observasi dan ketelitian } \\
\text { dalam prosesnya. Guru harus jeli dalam proses pembelajaran sehingga sikap } \\
\text { peserta didik dapat diidentifikasi yang kemudian dapat diberikan tindakan } \\
\text { lanjutan. Aspek ini tidak seperti aspek kognitif yang memiliki materi. Aspek } \\
\text { afektif tidak memiliki materi pokok sehingga ia diterapkan di dalam aspek-aspek } \\
\text { yang lain. }{ }^{21} \text { Maka dalam hal ini gurulah yang harus mampu meramu } \\
\text { pembelajaran sehingga tidak hanya mengasah kognitif seperta didik tetapi juga } \\
\text { mengembangkan afektif mereka. }\end{array}$} \\
\hline
\end{tabular}

\section{Aspek Sikap Spiritual}

Aspek sikap spiritual adalah aspek pembelajaran yang berfokus pada pembiasaan sikap spiritual kepada peserta didik. Selain dibiasakan aspek ini juga dinilai. Menurut Kunandar dalam Ruvina Windarisni bahwaevaluasi sikap sosial merupakan evaluasi yang mengukur sejauh mana kemampuan sikap siswa yang

${ }^{19}$ Pohan, "Pelaksanaan Proses Belajar Melalui Bimbingan Aspek Afektif, Kognitif Dan Psikomotorik Siswa Di Madrasah Ibtidaiyah Swasta Amal Shaleh Medan.”

${ }^{20}$ Pulungan, "Pembelajaran Ranah Afektif Antara Harapan Dan Kenyataan."

${ }^{21}$ Oviana, "Kemampuan Mahasiswa Mengintegrasikan Sikap Spiritual Dan Sosial Dalam Pembelajaran Berbasis Kurikulum 2013 (Kajian Teoritis)." 
dicapai, meliputi penerimaan atau partisipasi (receiving atau attending), tanggapan (responding), mengevaluasi atau menghargai (valuing), pengorganisasian atau manajemen (organization), dan memiliki ciri kepribadian (characterization). ${ }^{22}$

Dalam aspek ini terdapat kompetensi inti yang berbunyi menghayati dan mengamalkan ajaran agama yang dianutnya. Dalam hal pembelajaran fikih di madrasah aliyah maka agama yang dimaksud adalah agama Islam. Jadi kompetensi inti ini bertujuan untuk menerapkan sikap menghayati dan mengamalkan ajaran agama Islam pada individu siswa. Kompetensi inti ini terjabarkan ke dalam beberapa kompetensi dasar yang dikategorikan penulis sebagai berikut.

Pertama, menerima dan menyadari bahwa semua materi yang diajarkan dalam pembelajar fikih merupakan anugerah Allah swt. Menghayati dan mengamalkan semua yang telah diajarkan untuk hal-hal yang baik adalah sebagai wujud syukur atas anugerah Allah swt. Disesuaikan dengan pendapat Krathwol yakni tingkatan awal aspek afektif adalah menerima. Menerima maksudnya adalah peserta didik memberi perhatian terhadap peristiwa atau aktifitas yang dihadapi. Menurut Krathwohl, menerima dalam hal ini didefinisikan sebagai proses pembentukan sikap dengan meningkatkan kesadaran akan adanya rangsangan estetika tertentu. ${ }^{23}$ Guru dapat melakukan penerapan poin ini pada setiap permulaan pembelajaran atau pada pertemuan perdana di awal semester.

Pada pembelajaran luring guru dapat memberikannya dalam bentuk nasehat dan wejangan saat membuka pelajaran. Sedangkan pada pembelajaran daring, guru dapat mengkreasikannya tidak hanya dalam bentuk nasehat secara langsung.

Jauh lebih baik menggunakan media video atau cuplikan film yang menerangkan dan mengandung poin menghayatisemua materi yang diajarkan dalam pembelajar fikih sebagai anugerah dari Allah swt. Untuk pilihan video ini lebih cocok pada pembelajaran luring dengan menggunakan aplikasi video conferenceseperti Zoom Meeting atau Skype. Segera setelah video tersebut diputarkan dan ditonton oleh para peserta didik, guru menanyakan hal-hal yang menjurus ke kesyukuran terhadap nikmat bisa beribadah. Hal ini dilakukan dengan memberi pertanyaan-pertanyaan kritis terhadap peserta didik. Selain untuk merangkang kemampuan high order thinking skills tetapi juga membantu guru dalam melakukan "pemanasan" sebelum pembelajaran berlangsung.

\footnotetext{
${ }^{22}$ Windarisni, "Pengelolaan Penilaian Sikap Sosial Dalam Pembelajaran Muatan Lokal Bahasa Jawa Di Kelas II SDN Bayan No 216 Surakarta."

${ }^{23}$ Rozak, "EVALUASI AFEKTIF DALAM PEMBELAJARAN."
} 
Sementara itu pembelajaran daring tanpa menggunakan aplikasi video conference guru dituntut untuk lebih kreatif lagi dalam menerapkan poin ini, seperti layanan Google Classroom terdapat rubrik materi sehingga memungkinkan guru mengunggah video atau sekedar menyalin tautan sehingga peserta didik dapat langsung mengklik tautan tersebut. Adapun untukpilihan penggunaan video juga dapat dilakukan dengan menambahkan pertanyaan-pertanyaan yang merangsang respon peserta didik sama halnya dengan saat menggunakan aplikasi video conference. Aplikasi bukanvideo conference yang cukup sering digunakan untuk pembelajaran daring adalah Whatsapp. Whatsapp dengan layanannya yang sederhana ternyata dapat dimanfaatkan untuk meningkatkan kemampuan peserta didik. Sebagaimana dikemukakan oleh Kartikawati dan Pratama pada penelitian mereka bahwasanya penggunaan Whatsapp, sebagai metode survei kelompok komprehensif pembelajaran seluler, dapat digunakan secara efektif dapat meningkatkan kemampuan berpikir kritis siswa dalam proses pembelajaran. Rancangan pembelajaran yang dilaksanakan meliputi permulaan, pengelompokan, perencanaan, penyajian, pengorganisasian, penelitian, evaluasi, dan pengakhiran kemampuan berpikir mandiri dan berpikir kritis dapat diusahakan melalui soal-soal dalam kelompok. ${ }^{24}$

Kedua, meyakini menghayati dan menghargai bahwa pembelajaran fikih merupakan sarana untuk memahami ajaran Islam, baik yang berbentuk syariat ataupun fikih. Artinya peserta didik diharapkan mampu memahami bahwa pembelajaran fikih sangat erak kaitannya dengan agama Islam seperti dengan menanamkan kesadaran bahwa dengan pembelajaran fikih, siswa dapat mengetahui bagaimana tatacara beribadah sesuai dengan apa yang di ada dalam Al-quran, hadits dan berbagai pemahaman para ulama.

Menanamkan pemahaman dan kesadaran bahwa pembelajaran fikih sangat erat kaitannya dengan Islam saat pembelajaran daring dapat dilakukan dengan berbagai cara. Salah satu caranya adalah dengan sebanyak mungkin memasukkan contoh-contoh dari Alquran dan Hadis ke dalam materi ataupun soal-soal ujian. Metode ini dapat dilakukan baik dalam pembelajaran daring maupun luring, aspek afektif diajarkan di sela-sela pembelajaran aspek kognitif.

Dengan seringnya penerapan cara-cara yang telah disebutkan di atas, peserta didik diharapkan bukan hanya melaksanakannya karena tuntutat pendidikan formal tapi karena munculnya kesadaran pribadi dari diri peserta didik sendiri. Sebab menurut Rozak, alasan terjadinya perilaku ini bukan karena siswa benar-benar memenuhi kebutuhan sikap dan perilaku tersebut, tetapi

\footnotetext{
${ }^{24}$ Kartikawati and Pratama, "Pengaruh Penggunaan WhatsApp Messenger Sebagai Mobile Learning Terintegrasi Metode Group Investigation Terhadap Kemampuan Berpikir Kritis."
} 
karena mereka patuh pada aturan dan tata tertib, bukan karena takut akan dihukum. ${ }^{25}$ Pembiasaan ini bertujuan untuk membentuk dan mengubah sikap peserta didik.

Pemanfaatan sosial media dan media pemebelajaran online lainnya,baik untuk digunakan dalam pembelajaran. Sebagaimana dikemukakan oleh M. Yusuf Amin Nugrohobahwa media pembelajaran online dapat membuat pembelajaran fikih menjadi lebih menyenangkan dan menarik, memungkinkan siswa untuk belajar secara aktif, berinteraksi dan luwes, serta dapat meningkatkan semangat siswa dan digunakan sebagai sarana untuk membimbing siswa dalam menggunakan internet dengan lebih bijak. ${ }^{26}$

\section{Aspek Sikap Sosial}

Kompetensi inti untuk aspek sikap sosial ini berbunyi;Menunjukkan perilaku jujur, disiplin, bertanggung jawab, peduli (gotong royong, kerja sama, toleran, damai), santun, responsif, dan proaktif sebagai bagian dari solusi atas berbagai permasalahan dalam berinteraksi secara efektif dengan lingkungan sosial dan alam serta menempatkan diri sebagai cerminan bangsa dalam pergaulan dunia. Kompetensi ini kemudian diuraikan menjadi kompetensikompetensi dasar yang terbagi di setiap bab pembahasannya. Sikap-sikap sosial yang disyaratkan adalah jujur, disiplin, tanggung jawab, peduli, santun, responsif, dan proaktif. Sikap-sikap tersebut harus mampu dipahami dan dilaksanakan oleh peserta didik dengan bimbingan oleh guru fikih.

Perilaku jujur dan disiplin dapat diterapkan melalui ketepatan waktu saat mengikuti pembelajaran. Misalkan disiplin waktu saat memasuki meeting di zoom atau aplikasivideo conference lainnya. Peserta didik diberikan waktu 15 menit untuk masuk ke dalam meeting. Bagi siapa yang tidak masuk dalam masa waktu tersebut maka dia tidak boleh mengikuti pembelajaran di hari itu atau akan mendapatkan hukuman lain dari guru. Jika di kelas, pintu yang akan ditutup untuk para peserta didik yang terlambat, maka di pembelajaran daring ini meeting yang akan ditutup untuk mereka. Hal ini perlu dibiasakan sebab pembelajaran dari rumah seperti ini sedikit banyak telah memengaruhi ketepatan waktu peserta didik. Berdalih tidak perlu kemana-mana dan pembelajaran dapat langsung diakses di kamar sendiri, membuat para peserta didik cenderung menyepelekan ketepatan waktu sehingga banyak terjadi keterlambatan yang mengakibatkan waktu belajar terbuang sebagian hanya untuk menunggu peserta didik lain yang lambat masuk ke meeting.

\footnotetext{
${ }^{25}$ Rozak, "EVALUASI AFEKTIF DALAM PEMBELAJARAN."

${ }^{26 N u g r o h o, ~ " P E M A N F A A T A N ~ D A N ~ P E N G E M B A N G A N ~ B L O G ~ S E B A G A I ~}$ MEDIA DAN SUMBER BELAJAR PADA MATA PELAJARAN FIQIH TINGKAT MADRASAH TSANAWIYAH."
} 
Perilaku jujur dan disiplin juga dapat dilatihkan pada pemberian dan pengumpulan tugas. Guru harus mempertimbangkan tugas yang diberikan agar dapat memastikan kejujuran peserta didik. Misalkan memberikan tugas tertulis yang harus ditulis tangan oleh peserta didik. Tugas yang diberikan juga harus memiliki batas waktu pengumpulan yang tegas sehingga peserta didik terlatih dan terbiasa untuk disiplin utamanya dalam hal waktu. Guru harus tegas dalam mengambil kebijakan. Misalkan ada peserta didik yang terlambat mengumpulkan tugas dengan alasan yang tidak dapat diterima, maka guru harus menerapkan hukuman yang pantas.

Selanjutnya yaitu sikap tanggung jawab dan peduli (gotong royong, kerja sama, toleran, damai). Tanggung jawab adalah kesadaran manusia atas perilaku atau tindakan yang disengaja atau tidak disengaja, dan artinya menunjukkan pemahaman tentang kewajiban seseorang. ${ }^{27}$ Jika dikaitkan dengan sikap tanggung jawab, guru juga harus memastikan kebenaran pekerjaan peserta didik. Maksudnya guru harusmemastikan bahwa peserta didik benar-benar bertanggung jawab atas tugasnya. Apakah ia mengerjakannya sendiri atau dikerjakan oleh orang lain. Dalam hal ini guru juga harus mampu menginterogasi peserta didik utamanya peserta didik yang mencurigakan. Terlebih lagi jika ada tugas yang dikerjakan berkelompok. Guru harus tegas memberikan tindakan kepada peserta didik yang tidak kooperatif dengan kelompoknya. Guru juga harus kembali menginterogasi seluruh anggota kelompok untuk mengidentifikasi peserta didik yang mana yang tidak ikut mengerjakan.

Selanjutnya yaitu peduli, sikap kepedulian yang berisi rasa gotong royong, kerja sama, toleran (toleransi adalah sikap dan tindakan yang menghargai perbedaan $)^{28}$ dan damai dalam pembelajaran daring dapat diimplementasikan ketika pemberian tugas kelompok. Dalam pembagian kelompok guru bisa mengkondisikan dalam suatu kelompok terdiri dengan siswa yang memiliki kemampuan kognitif yang bervariasi, dengan itu diharapkan siswa yang memiliki pemahaman yang lebih terhadap materi bisa membantu menjelaskan apa yang tidak dipahami teman kelomponya yang lain. Dalam penugasan kelompok pada pembelajaran daring tersebut dapat membentuk sikap gotong royong dan kerja sama ketika dalam teknis pengerjaannya dengan membagi tugas dengan proporsinya masing-masing, juga dapat muncul sikap toleran jika ketika salah satu siswa terdapat kendala dalam hal teknis jaringan.

\footnotetext{
${ }^{27}$ Anwar, "TANGGUNG JAWAB PENDIDIKAN DALAM PERSPEKTIF PSIKOLOGI AGAMA."

${ }^{28}$ Lena, Nelson and Siswanto "IMPLEMENTASI NILAI-NILAI KARAKTER MENURUT KEARIFAN LOKAL

MASYARAKAT LEMBAK KECAMATAN BINDURIANG"
} 
Dengan terciptanya pengerjaan tugas kelompok dengan sikap kepedulian satu sama lain, maka rasa damai dalam pembelajaran dapat dirasakan.

Sikap santun peserta didik dapat dilihat dari tutur katanya saat mengikuti pembelajaran. Di dalam meeting video conference misalkan, sebut saja sedang diadakan diskusi antara peserta didik. Guru harus selalu memantau apa yang didiskusikan peserta didik. Selain untuk mencegah melebarnya pembahasan, guru juga dapat menilai sikap santun peserta didik. Bahkan jika ada peserta didik yang mengeluarkan kata-kata tidak baik, ataupun hanya pasif saat diskusi, atau bahkan meninggalkan meeting saat diskusi, guru dapat langsung menegur peserta didik bersangkutan. Masih berkaitan dengan itu guru juga dapat mengapresiasi peserta didik sekaligus memberikan dorongan kepada mereka untuk lebih responsif, dan proaktif dalam proses diskusi serta dalam menyampaikan argumennya.

\section{KESIMPULAN}

Pandemi covid-19 merupakan suatu realitas yang harus diterima oleh setiap insan di dunia pendidikan. Guru sebagai aktor yang sangat penting dalam pendidikan harus mampu menyesuaikan dengan keadaan. Guru dapat mengajarkan aspek kognitif kepada peserta didik dengan mudah tetapi tidak dengan afektif. Ditambah lagi dengan pembelajaran jarak jauh yang membuat aspek sikap spiritual dan sosial K13 cenderung terabaikan. Guru wajib mampu meramu strategi dan metodenya dalam penerapan ketiga aspek pembelajaran utamanya afektif dalam pembelajaran daring. Penerapan atau implementasi dari sebuah kurikulum itu sangat penting sekali, karena jika teori hanya akan sekedar menjadi teori jika tidak diimplementasikan dalamkehidupan sehari-hari. ${ }^{29}$

Teori tingkatan-tingkatan domain afektif menurut Taksonomi Bloom yaitu: Receiving (attending), Responding, Valuing, Organization dan Characterization by value (value complex) dapat diimplementasikan dalam pembelajaran daring jika guru bias menyesuaikan metode pembelajaran dan dengan cermat memanfaatkan teknologi media pembelajaran daring yang ada. Adapun cara-cara atau metode yang dapat dikembangkan oleh guru terkait penerapan aspek afektif dalam pembelajaran daring itu sangat bervariasi. Guru dapat mengombinasikannya dengan materi, penugasan, kehadiran, dan keaktifan peserta didik saat pembelajaran. Metode juga dapat disesuaikan dengan aplikasi atau layanan yang digunakan untuk pembelajaran. Tidak ada pakem khusus

\footnotetext{
${ }^{29}$ Kartikasari and Mujib, "Hambatan Pengimplementasian Kurikulum 2013 Pada Proses Pembelajaran Universalime Islam (PAI).”
} 
dalam pelaksanaannya, cukup dari kreatifitas dan flesibilitas guru dalam memainkan dan mengombinasikan strateginya dalam mengajar.

Dengan demikian guru dituntut untuk lebih paham dalam penggunaan teknologi. Sebab tidak dapat dikesampingkan bahwa zaman senantiasa berkembang dan banyak sekali perkembangan yang wajib untuk disesuaikan dan dimanfaatkan untuk kebutuhan dunia pendidikan khususnya dalam pembelajaran fikih.

\section{BIBLIOGRAFY}

Anwar, Shabri Shaleh. "TANGGUNG JAWAB PENDIDIKAN DALAM PERSPEKTIF PSIKOLOGI AGAMA." Psympathic: Jurnal Ilmiah Psikologi 1, no. 1 (June 30, 2014): 11-21. https://doi.org/10.15575/psy.v1i1.463.

Cronbach, Lee. Educational Psychology. Grace: New Harcourt, 1954.

Dewi, Wahyu Aji Fatma. "Dampak COVID-19 Terhadap Implementasi Pembelajaran Daring Di Sekolah Dasar." EDUKATIF: JURNAL ILMU PENDIDIKAN 2, no. 1 (April 29, 2020): 55-61. https://doi.org/10.31004/edukatif.v2i1.89.

Garry, Ralph, Howard L., and Kingsley. The Nature and Conditions of Learning. Engliwood Clifts: Prentice-Hall, 1970.

Hamzah, Syeh Hawib. "Aspek Pengembangan Peserta Didik: Kognitif, Afektif, Psikomotorik." Dinamika Ilmu 12, no. 1 (2012): 1-22.

Kartikasari, Devfy, and Zulfikar Mujib. "Hambatan Pengimplementasian Kurikulum 2013 Pada Proses Pembelajaran Universalime Islam (PAI).” Belajea; Jurnal Pendidikan Islam 5, no. 2 (December 30, 2020): 181. https://doi.org/10.29240/belajea.v5i2.1606.

Kartikawati, Sulistyaning, and Hendrik Pratama. "Pengaruh Penggunaan WhatsApp Messenger Sebagai Mobile Learning Terintegrasi Metode Group Investigation Terhadap Kemampuan Berpikir Kritis." JUPITER (JURNAL PENDIDIKAN TEKNIK ELEKTRO) 2, no. 2 (October 30, 2017): 33. https://doi.org/10.25273/jupiter.v2i2.1797.

Lena, Nelson and Siswanto "IMPLEMENTASI NILAI-NILAI KARAKTER MENURUT KEARIFAN LOKALMASYARAKAT LEMBAK KECAMATAN BINDURIANG" PARAMUROBI: JURNAL PENDIDIKAN $\begin{array}{llll}A G A M A & \text { ISLAM } & 3 & \text { (2), }\end{array}$ https://doi.org/10.32699/paramurobi.v3i2.1388.

Madrasah, Kami. "KMA 183 Tahun 2019 Tentang Kurikulum PAI Dan Bahasa Arab." kamimadrasah.blogspot.com, 
https://kamimadrasah.blogspot.com/2019/08/kma-183-tahun-2019-

kurikulum-pai-dan-bahasa-arab.html.(diakses 16 Januari 2021)

Nugroho, Yusuf Amin. "PEMANFAATAN DAN PENGEMBANGAN BLOG SEBAGAI MEDIA DAN SUMBER BELAJAR PADA MATA PELAJARAN FIQIH TINGKAT MADRASAH TSANAWIYAH." PARAMUROBI: JURNAL PENDIDIKAN AGAMA ISLAM 1, no. 1 (June 15, 2018): 15-28. https://doi.org/10.32699/paramurobi.v1i1.175.

Oviana, Wati. "Kemampuan Mahasiswa Mengintegrasikan Sikap Spiritual Dan Sosial Dalam Pembelajaran Berbasis Kurikulum 2013 (Kajian Teoritis)." PIONIR: Jurnal Pendidikan 4, no. 2 (2015): 1-12.

Pohan, Nurbiah. "Pelaksanaan Proses Belajar Melalui Bimbingan Aspek Afektif, Kognitif Dan Psikomotorik Siswa Di Madrasah Ibtidaiyah Swasta Amal Shaleh Medan." Repository Universitas Islam Negeri Sumatera Utara. Universitas Islam Negeri Sumatera Utara, 2017.

Pranjia, Ufara Rizki, Indah Maria Ulpa, and Suci Putri Manthika. "IMPLEMENTASI SIKAP SPIRITUAL DAN SIKAP SOSIAL DALAM SISTEM FULL DAY SCHOOL." Jurnal Pendidikan Islam 11, no. 1 (May 31, 2020): 31-43. https://doi.org/10.22236/jpi.v11i1.5032.

Pulungan, Muhammad Yusuf. "Pembelajaran Ranah Afektif Antara Harapan Dan Kenyataan." Darul 'ilmi 01, no. 02 Juli (2013): 45-76.

Qadar, Riskan. "Mengakses Aspek Afektif Dan Kognitif Pada Pembelajaran Optika Dengan Pendekatan Demonstrasi Interaktif." Jurnal Inovasi Dan Pembelajaran Fisika 2, no. 1 (2015): 1-11.
Rozak, Purnama.
"EVALUASI
AFEKTIF
DALAM

PEMBELAJARAN." Madaniyah 4, no. 1 (2014): 58-77.

Sari, Widya, Andi Muhammad Rifki, and Mila Karmila. "Pembelajaran Jarak Jauh Pada Masa Darurat Covid 19." Jurnal MAPPESONA, no. 1 (2020): 12. https://jurnal.iain-bone.ac.id/index.php/mappesona/article/view/830.

Semradova, Ilona, and Sarka Hubackova. "Teacher Responsibility in Distance Education." Procedia - Social and Behavioral Sciences 217 (2016): 544-50. https://doi.org/10.1016/j.sbspro.2016.02.042.

Sudarsana, I Ketut, Ni Gusti Ayu Made Yeni Lestari, I Komang Wisnu Budi Wijaya, Astrid Krisdayanthi, Komang Yuli Andayani, Komang Trisnadewi, Ni Putu Sasmika Dewi Suparya Ni Made Muliani, et al. Covid-19: Perspektif Pendidikan. Edited by Kadek Aria Prima Dewi PF and Janner Simarmata. Cetakan 1. Medan: Yayasan Kita Menulis, 2020.

Suliswiyadi, Suliswiyadi. "Hierarki Ranah Pembelajaran Afektif Pendidikan Agama Islam Dalam Perspektif Taksonomi Qur'ani.” Jurnal Tarbiyatuna 11, no. 1 (June 1, 2020): 61-76. https://doi.org/10.31603/tarbiyatuna.v11i1.3451.

Wicaksono, Soetam Rizky. "Strategi Penerapan Domain Afektif Di Lingkup Perguruan Tinggi." Jurnal Pendidikan 12, no. 2 (2011): 112-19. 
https://www.researchgate.net/publication/233903001_STRATEGI_PENERA PAN_DOMAIN_AFEKTIF_DI_LINGKUP_PERGURUAN_TINGGI.

Windarisni, Ruvina. "Pengelolaan Penilaian Sikap Sosial Dalam

Pembelajaran Muatan Lokal Bahasa Jawa Di Kelas II SDN Bayan No 216 Surakarta." Universitas Muhammadiyah Surakarta., 2016. 